\title{
KOMUNIKASI INTERPERSONAL GURU DALAM MENINGKATKAN MOTIVASI BERPRESTASI REMAJA TUNA RUNGU
}

\author{
Febry Prapaskah Rino ${ }^{1}$, Siti Maryam², Anjang Priliantini ${ }^{3}$ \\ 1,2,3 Universitas Pembangunan Nasional "Veteran" Jakarta \\ Jl. RS. Fatmawati, Pondok Labu, Jakarta Selatan, Daerah Khusus Ibukota Jakarta, 12450, Indonesia \\ No. Telp./HP: ${ }^{1} 089677678081,{ }^{2} 081225644625,{ }^{3} 081327175159$ \\ E-mail: ${ }^{1}$ fbrprpskh@gmail.com, ${ }^{2}$ stmaryam@ymail.com, ${ }^{3}$ anjangpriliantini6@gmail.com
}

Naskah diterima tanggal 6 Desember 2019, direvisi tanggal 29 Juni 2020, disetujui tanggal 19 Agustus 2020.

\section{TEACHER INTERPERSONAL COMMUNICATION IN INCREASING ACHIEVEMENT MOTIVATION OF DEAF ADOLESCENT}

\begin{abstract}
Deaf adolescents have a relatively high-level need for freedom, dependence, attention, and support. Meanwhile, the need that is hampered by fulfillment is the need for achievement. This study aims to present a description of teacher interpersonal communication in increasing the achievement motivation of deaf adolescents. The theory and research concepts used are Symbolic Interaction Theory, Humanistic Approach, and the concept of nonverbal behavior. The research method used is a qualitative type with a phenomenological approach. The results showed that the experience of teachers' interpersonal communication in increasing achievement motivation of deaf adolescents was carried out with a humanistic approach such as building and maintaining warm relationships, teaching trust, openness, awareness, understanding the feelings, and interpersonal honesty, and equality. It also focused on the perspective of symbolic interactions, such as instilling the ability to think in solving problems, applying quality self-concepts, and involving the community to meet the needs of interacting and prioritizing the importance of nonverbal behavior.
\end{abstract}

Keywords: interpersonal communication, achievement motivation, deaf adolescent.

\begin{abstract}
Abstrak. Remaja tuna rungu mempunyai kebutuhan yang cukup tinggi atas kebebasan (need of autonomy), ketergantungan (need of succorance), perhatian, dan dukungan (need of exhibition). Sedangkan kebutuhan yang terhambat pemenuhannya ialah kebutuhan untuk berprestasi (need of achievement). Penelitian ini bertujuan untuk memaparkan gambaran komunikasi interpersonal guru dalam meningkatkan motivasi berprestasi remaja tuna rungu. Teori dan konsep penelitian yang digunakan adalah teori interaksi simbolik, pendekatan humanistis, serta konsep perilaku nonverbal. Metode penelitian yang digunakan adalah jenis kualitatif dengan pendekatan fenomenologi. Hasil penelitian menunjukkan bahwa pengalaman komunikasi interpersonal guru dalam meningkatkan motivasi berprestasi remaja tuna rungu dilakukan dengan pendekatan humanistis dengan membangun dan menjaga hubungan yang akrab, menunjukkan rasa percaya, terbuka, adanya kesadaran, menunjukkan adanya upaya memahami perasaan, kejujuran interpersonal, dan perasaan setara. Selain itu juga menitikberatkan pada perspektif interaksi simbolik seperti menanamkan kemampuan berpikir dalam menyelesaikan permasalahan, menerapkan konsep diri yang berkualitas, dan melibatkan masyarakat untuk memenuhi kebutuhan berinteraksi dan mengedepankan pentingnya perilaku nonverbal.
\end{abstract}

Kata kunci: komunikasi interpersonal, motivasi berprestasi, remaja tuna rungu.

\section{PENDAHULUAN}

Komunikasi interpersonal adalah komunikasi yang dilakukan secara langsung saat bertatap muka atau melalui media, yang melibatkan individu-individu sehingga mereka dapat menangkap reaksi satu sama lain secara langsung, baik secara verbal atau nonverbal 
(Mulyana, 2015). Komunikasi interpersonal umumnya digunakan guru untuk melakukan pendekatan secara personal terhadap muridnya, termasuk juga bagi yang berkebutuhan khusus seperti penyandang tuna rungu. Namun, berkomunikasi dengan penyandang tuna rungu tidak cukup hanya menggunakan bahasa verbal maupun nonverbal dengan simbol-simbol. Pendekatan secara pribadi (interpersonal) yang diwujudkan dalam interaksi tatap muka juga diharapkan dapat membangun sikap saling memahami antara guru dan murid tuna rungu.

Tuna rungu adalah suatu keadaan kehilangan pendengaran yang mengakibatkan seseorang tidak dapat menangkap berbagai rangsangan, terutama melalui indera pendengarannya (Somantri, 2007). Hilangnya kemampuan mendengar otomatis juga menyebabkan kebisuan, karena individu tersebut tidak dapat mendengar berbagai bunyi yang seharusnya dipelajari. Hilangnya kemampuan mendengar dan berbicara ini pada penyandang tuna rungu disebut sebagai kelainan ganda, yaitu bisu tuli. Hal ini membawa dampak-dampak lainnya yang ditunjukkan anak penyandang tuna rungu, seperti meminta perhatian, pelayanan, pengertian, dan kesempatan sebaik - baiknya yang diberikan kepada penyandang tuna rungu.

Walau demikian, individu tuna rungu mampu mengoptimalkan fungsi indera lainnya, seperti indera penglihatan (Somantri, 2007) sehingga mereka cenderung cepat berkembang dalam hal motorik. Kemampuan motorik inilah yang mendukung kemampuan seorang tuna rungu dalam menangkap makna gerakan bibir lawan bicaranya dan bahasa isyarat sebagai media komunikasi utamanya.

Individu tuna rungu juga mempunyai keinginan untuk berkembang secara pemikiran, kemampuan, karakter, dan tingkah laku layaknya orang normal (Suparno, 2001). Mereka juga memiliki keinginan untuk menjadi pribadi yang mandiri. Meski memiliki kekurangan pada pendengarannya, para penyandang tuna rungu juga mempunyai hak yang sama, termasuk hak memperoleh pendidikan yang layak.

Pemahaman publik terhadap
penyandang disabilitas penuh dengan

penilaian diskriminatif atas perbedaan fisik dan kemampuan antara penyandang disabilitas dengan manusia normal (Widinarsih, 2019). Tentu hal tersebut dapat menjadi hambatan yang dapat mengarahkan individu pada suatu kehidupan yang terasing (isolated) dalam masyarakat. Soekanto (1990) juga memaparkan bahwa kehidupan terasing ditandai dengan ketidakmampuan untuk mengadakan interaksi sosial dengan pihakpihak lain. Kehidupan terasing dari ketidakmampuan berinteraksi pada penyandang tuna rungu dalam hal ini dicermati pada usia remaja, dikarenakan masa remaja dianggap sebagai masa yang paling sulit dalam tahap perkembangan individu. Para psikolog selama ini memberi label masa remaja sebagai masa storm dan stress, di mana pada masa inilah remaja menjalani proses evolusi menuju kedewasaan (Lestari, 2012).

Remaja penyandang tuna rungu dapat mengalami konflik diri saat menghadapi kenyataan bahwa kemampuan berinteraksi di ruang lingkup masyarakat menjadi sangat terbatas karena hambatan dalam berkomunikasi sebagaimana mestinya. Disfungsi pendengaran juga membuat anak tuna rungu mengalami keterlambatan dalam perkembangan sosio-emosi. Mereka mengalami kesulitan untuk memahami perasaan dan pikiran orang lain (Brown et al., 2000), sehingga mereka sering mengalami emosi negatif. Emosi negatif inilah yang membuat mereka tidak dapat berinteraksi dengan sesama. Mereka cukup sulit diterima dan dipahami oleh orang-orang di sekitarnya (Liben, 1978). Bersamaan dengan munculnya berbagai persepsi atau bahkan stigma tersendiri dari masyarakat juga dapat menghambat perkembangan potensi atau kemampuan remaja tuna rungu dalam menunjukkan identitasnya.

Terkait dengan pengembangan potensi dan kemampuan diri, remaja tuna rungu tidak jarang mengalami hambatan dan kendala dari segi sosial, emosional, maupun intelektualnya. Hal ini akan berakibat pada proses pendidikan dan pembelajaran remaja tuna rungu. Sehingga mereka tegantung pada orang lain dan adanya ketakutan untuk memasuki lingkungan yang lebih luas. Namun, remaja tuna rungu memiliki kemampuan yang ada di dalam diri mereka. 
Untuk bisa mengembangkan bakat/keterampilan mereka, salah satunya dengan memberikan dorongan untuk berprestasi sehingga dapat berdampak positif jangka panjang bagi penderita tuna rungu. Hal ini sesuai dengan penelitian yang dilakukan oleh Pranungsari, Tentama, dan Tarnoto (2016) bahwa pentingnya motivasi berprestasi bagi individu akan berdampak terhadap prestasi yang akan dicapainya, salah satunya adalah pencapaian prestasi belajar yang akan maksimal.

Keadaan yang hampir sama tercermin dalam penelitian berjudul "Profil Kebutuhan Psikologis Remaja Tuna Rungu" yang ditulis oleh Heryati (2012), seorang dosen Psikologi UPI Bandung menjelaskan bahwa remaja tuna rungu di SLB-B Cicendo Bandung mempunyai kebutuhan yang cukup tinggi akan kebebasan (need of autonomy), ketergantungan (need of succorance), perhatian, dan dukungan (need of exhibition). Sedangkan kebutuhan yang kurang atau terhambat pemenuhannya ialah kebutuhan untuk berprestasi (need of achievement).

Motif berprestasi ini mengarah pada kepentingan masa depan dibandingkan masa lalu atau masa kini, dan individu akan menjadi lebih kuat dalam menghadapi kegagalan karena dirinya dapat memperkirakan situasi yang akan datang untuk memperoleh prestasi yang lebih baik dalam bekerja. Selanjutnya Mc Clelland dalam Sukadji (2001) mengatakan bahwa individu yang memiliki kebutuhan berprestasi tinggi (high $n$-ach) lebih memiliki orientasi berpikir mengenai prestasi, berusaha lebih keras dalam meraih kesempatan dan mencapai tujuan. Sebaliknya, individu yang memiliki motivasi berprestasi rendah biasanya cenderung kurang atau tidak memiliki kepedulian untuk berusaha lebih keras. Mc Clelland dalam Sukadji (2001) juga mendorong bahwa kebutuhan berprestasi ( $n$ ach) bukan hasil dari turun-temurun (hereditary) melalui gen melainkan hasil dari pengaruh lingkungan, dan dia menemukan bahwa ada kemungkinan individu dalam mencapai motivasi berkembang lebih besar ketika mendapatkan bimbingan (training).

Dalam observasi yang dilakukan penulis di SLB Negeri 4 Jakarta, diketahui bahwa remaja tuna rungu mempunyai perasaan yang DOI: $10.20422 /$ jpk.v23i2.694 cenderung sensitif. Sikap sensitif tersebut ditunjukkan ketika ada orang di dekatnya sedang membicarakan sesuatu, mereka cenderung merasa tersinggung karena mengira dirinya sedang dibicarakan. Dalam situasi belajar-mengajar di kelas, bila diberikan suatu pertanyaan oleh guru pembimbing, mereka cenderung melempar pertanyaan tersebut kepada teman yang lainnya, karena merasa tidak percaya diri untuk menjawabnya. Selain itu, mereka juga cenderung terlihat kurang mampu bekerjasama.

Berangkat dari permasalahan yang ada, keterbatasan kemampuan siswa disabilitas termasuk remaja penyandang tuna rungu dalam mengakses dunia pendidikan menjadi persoalan penting yang harus diselesaikan pemerintah. Merujuk pada Data Pokok Pendidikan Dasar dan Menengah Nasional (Dapodikdasmen) Tingkat SLB DKI Jakarta, jumlah SLB di Jakarta ada 23 sekolah, delapan di antaranya berstatus sekolah negeri. Padahal, Pusat Data dan Informasi (Pusdatin) 2014 Kementerian Kesehatan RI, mengutip dari sensus penduduk pada tahun 2010, menyebutkan jumlah penyandang disabilitas di Jakarta sekitar 526 ribu orang. Sedangkan hanya 5.381 penyandang disabilitas di Jakarta yang merasakan bangku pendidikan. Sisanya, setara dengan $89,8 \%$ tidak menikmati pendidikan di SLB. Penyebab utama keadaan ini adalah kurangnya jumlah SLB di Jakarta (Senorita, Silalahi, dan Manullang, 2018).

SLB Negeri 4 Jakarta menjadi salah satu SLB dengan tingkat animo yang tinggi. Seperti pada tahun 2016, hanya 20 anak yang diterima dari 100 calon siswa yang mendaftar (Wandi, 2016). Walikota Jakarta Utara, Wahyu Hariyadi mengakui bahwa SLB Negeri 4 Jakarta minim tenaga pengajar. Menurutnya, saat ini di sekolah tersebut baru memiliki 40 guru yang menangani sebanyak 255 siswa yang terbagi dalam 32 kelas tingkat SD, SMP, dan SMA (Kementerian Pendidikan dan Kebudayaandikbud, 2020).

Kemampuan khusus guru SLB Negeri 4 Jakarta untuk berkomunikasi secara efektif dengan siswa tuna rungu merupakan hal mutlak. Sebab ada beberapa faktor yang dapat menghambat efektivitas komunikasi antarpribadi (Aw, 2011), seperti kredibilitas komunikator (dalam hal ini guru) rendah, guru 
kurang memahami latar belakang sosial dan budaya, guru kurang memahami karakteristik komunikan (dalam hal ini murid tuna rungu), prasangka negatif antara guru dan murid, guru berkomunikasi hanya dengan menggunakan komunikasi verbal, guru berkomunikasi dengan murid secara satu arah, guru tidak menggunakan media komunikasi yang tepat, serta adanya perbedaan bahasa dan persepsi.

Berdasarkan berbagai permasalahan yang telah dipaparkan di atas, penulis secara khusus ingin memaparkan gambaran komunikasi interpersonal guru dalam meningkatkan motivasi berprestasi remaja tuna rungu di SLB Negeri 4 Jakarta. Sehingga penelitian ini diharapkan mampu menambah pengetahuan terkait upaya membangun komunikasi interpersonal dengan remaja tuna rungu, terutama dalam upaya meningkatkan motivasi berprestasi.

\section{LANDASAN KONSEP}

Untuk menjawab tujuan penelitian tersebut, penelitian ini menggunakan teori komunikasi antarpribadi, yang mencakup pendekatan humanistis (Devito, 2011), interaksi simbolik (Mead dalam Ardianto, Komala, dan Karlinah, 2007), dan komunikasi nonverbal (Budyatna dan Ganiem, 2011) sebagai koridornya. Ketiga pendekatan yang digunakan dalam penelitian ini berfungsi untuk mencapai asumsi teori komunikasi antarpribadi, yaitu tercapainya komunikasi yang efektif antara dua orang yang terlibat, dalam hal ini guru dan murid tuna rungu di SLB Negeri 4 Jakarta. Ditetapkannya tiga pendekatan sebagai koridor dalam penelitian ini juga dimaksudkan untuk menghindari pembahasan di luar fokus penelitian.

Secara rinci, dengan menggunakan pendekatan humanistis (Devito, 2011) maka penelitian ini akan menggali pengalaman guru SLB Negeri 4 Jakarta dalam meningkatkan motivasi berprestasi siswa tuna rungu melalui keterbukaan (openness), sikap empati (empathy), sikap mendukung (supportiveness), sikap positif (positiveness), dan kesetaraan (equality).

Secara rinci, teori interaksi simbolik dalam penelitian ini akan menggali pengalaman guru SLB Negeri 4 Jakarta dalam meningkatkan motivasi berprestasi siswa tuna rungu melalui tiga konsep, yaitu pikiran (mind), diri (self), dan masyarakat (society). Relasi dari ketiga konsep tersebut adalah pikiran manusia (mind) dan interaksi sosial (self) digunakan untuk menginterpretasikan makna atas segala hal yang terjadi di lingkungan masyarakat (society) tempat kita hidup. Proses pemaknaan ini dikaji dalam tradisi interaksionisme simbolik (Ardianto, Komala, dan Karlinah, 2007).

Interaksi simbolik didasarkan pada proses interaksi individu dengan masyarakat. Esensi interaksi simbolik adalah suatu aktivitas komunikasi, terutama pemaknaan atas terjadinya pertukaran simbol. Dengan kata lain, dapat dikatakan bahwa premis-premis dalam teori interaksi simbolik yaitu, pertama, individu merespon suatu situasi simbolik yang ada di lingkungan sosialnya (Mulyana, 2015). Kedua, makna adalah produk interaksi sosial, karenanya makna suatu objek tidak bersifat mutlak, melainkan dinegosiasikan dengan kelompok sosial tersebut (Mulyana, 2015). Hal ini menyebabkan premis ketiga, bahwa makna yang diinterpretasikan individu bersifat dinamis atau dapat berubah dari waktu ke waktu seiring dengan perubahan yang terjadi dalam lingkungan sosial tersebut (Mulyana, 2015).

Koridor ketiga dalam penelitian ini adalah menggunakan pendekatan komunikasi nonverbal yang dilakukan oleh guru SLB Negeri 4 Jakarta dalam meningkatkan motivasi berprestasi siswa tuna rungu. Komunikasi nonverbal menurut Mark L. Knapp dalam (Dasrun, 2012) berfungsi sebagai upaya pengulangan dari bahasa verbal (repetisi), menggantikan lambang-lambang verbal (substitusi), menolak atau memberi makna lain terhadap pesan verbal (kontradiksi), melengkapi dan memperkaya makna pesan verbal (komplemen), dan menegaskan pesan verbal (aksentuasi).

Beberapa bentuk komunikasi nonverbal (Budyatna dan Ganiem, 2011) yang akan digali dalam penelitian ini antara lain (1) kinesics, yaitu gerakan tubuh yang meliputi kontak mata, ekspresi wajah, gerak isyarat, postur atau perawakan, dan sentuhan; dan paralanguage, yaitu "suara" nonverbal yang 
meliputi tinggi atau rendahnya nada vokal (pola titinada), keras atau lembutnya suara nada (volume), kecepatan berbicara, dan kualitas bunyi dari suara seseorang ketika berbicara.

\section{METODE PENELITIAN}

Jenis penelitian yang digunakan adalah penelitian lapangan dengan metode kualitatif. Pendekatan yang digunakan adalah fenomenologi. Fenomenologi mempelajari pengalaman yang aktual individu. Hal ini disampaikan oleh Littlejohn, Foss, \& Oetzel (2012), bahwa fenomenologi dapat diartikan sebagai suatu tampilan dari objek, kejadian, atau kondisi-kondisi menurut persepsi.

Sumber data yang digunakan dalam penelitian kualitatif ini terdiri atas data primer dan sekunder (Sugiyono, 2017). Data primer adalah data yang diperoleh oleh peneliti secara langsung dari individu atau perseorangan melalui aktivitas wawancara atau pengisian kuesioner (Kountur, 2008). Untuk mendapatkan data dan informasi mengenai pengalaman komunikasi interpersonal, data primer didapat melalui observasi dan wawancara dengan guru pembimbing remaja tuna rungu. Sedangkan data sekunder adalah data yang relevan dengan topik penelitian namun telah diolah oleh pihak lain (Kountur, 2008) seperti buku, jurnal, berita, dokumentasi, laporan tahunan, dan dokumendokumen relevan lainnya yang dianggap perlu untuk melengkapi penelitian ini.

Subjek penelitian adalah sumber informasi yang digali untuk mengungkap fakta-fakta di lapangan. Penentuan subjek pada penelitian kualitatif didasarkan pada kebutuhan atas informasi tertentu. Karenanya, dalam penelitian ini digunakan teknik pengambilan sampel purposive sampling, yaitu teknik pengambilan sampel yang ditentukan dengan menyesuaikan pada tujuan penelitian atau pertimbangan tertentu (Satori dan Komariah, 2014). Adapun yang menjadi subjek dalam penelitian ini dapat dilihat pada Tabel 1.

Ketiganya mempunyai peran penting sebagai fasilitator untuk melaksanakan berbagai kegiatan proses belajar anak tuna rungu di dalam sekolah dan mengarahkan siswanya untuk mencapai motivasi berprestasi. Selain itu, penelitian ini juga melibatkan beberapa siswa tuna rungu di SLB Negeri 4 Jakarta untuk diobservasi dan diwawancara secara tidak terstruktur guna mengonfirmasi tindakan ketiga subjek utama penelitian.

Setelah data terkumpul, selanjutnya data dianalisis. Analisis data diawali dengan penelusuran data penelitian, dilanjutkan dengan menglasifikasikan data tersebut ke dalam unit-unit analisis. Selanjutnya dilakukan sintesis dan penyusunan pola sesuai dengan aspek yang diteliti untuk melihat prediksi hasil penelitian. Kemudian diakhiri dengan membuat simpulan dan laporan (Yusuf, 2017). Data yang telah dianalisis harus dipastikan keabsahannya.

Tabel 1

Daftar Subjek Penelitian

\begin{tabular}{cccc}
\hline No. & Nama & Jabatan & Keterangan \\
\hline \multirow{2}{*}{$\mathbf{2}$} & Jailim & Pendidik Anak & Narasumber \\
& Tuna Rungu & 1 \\
$\mathbf{2}$ & Mika Nur & Pendidik Anak & Narasumber \\
& Cahyani & Tuna Rungu & 2 \\
& & Kepala SLB & Narasumber \\
$\mathbf{3}$ & Sentono & Negeri 4 & 3 \\
& & Jakarta & \\
\hline
\end{tabular}

Sumber: Hasil Penelitian

\section{HASIL PENELITIAN DAN PEMBAHASAN}

Penelitian ini bertujuan untuk mengeksplorasi pengalaman pribadi yang dialami dan dilalui guru pembimbing dalam menjalin komunikasi interpersonal dengan remaja tuna rungu di SLB Negeri 4 Jakarta, khususnya dalam konteks upaya meningkatkan motivasi berprestasi.

Hasil wawancara memperlihatkan bahwa guru di SLB Negeri 4 Jakarta merasakan keterikatan yang kuat dengan remaja tuna rungu. Menurut Kepala Sekolah SLB Negeri 4 Jakarta, Sentono, ada tiga alasan pentingnya menjalin komunikasi secara aktif dan terbuka: "Tiga alasan mengapa penting untuk menjalin komunikasi secara aktif dan terbuka antara guru dengan siswa disabilitas, terutama tuna rungu yang telah memasuki masa remaja. Pertama, dapat mengetahui cara memahami komunikasi nonverbalnya. Kedua, 
dapat menjelaskan tentang pentingnya terus belajar agar mendapatkan pengalaman dan ijazah yang bisa digunakan untuk bekal hidupnya. Serta yang ketiga, anak akan termotivasi dengan melihat tingkah laku gurunya yang terus bersemangat dan berprestasi mengajari anak-anak tanpa lelah" (Sentono, Kepala Sekolah SLB Negeri 4 Jakarta).

Data temuan penelitian mengindikasikan bahwa kedua narasumber dalam penelitian ini menyatakan keterikatan yang didasarkan pada cara pendekatan dan cara bertingkah laku. Sementara itu, alasan lain dilakukan pendekatan secara aktif dan terbuka tidak lepas kaitannya dengan upaya untuk menumbuhkan motivasi berprestasi.

Ketika dikaitkan dengan teori pendekatan humanistis, temuan penelitian menunjukkan bahwa salah satu syarat terjadinya komunikasi yang efektif guna membangun motivasi berprestasi adalah adanya salah satu aspek pendekatan humanistis sebagaimana dikemukakan oleh Devito (2011), yaitu adanya aspek keterbukaan seperti berkomunikasi secara aktif dan terbuka.

Di samping itu, keterbukaan yang berkualitas setidaknya harus memenuhi tiga aspek dari komunikasi antarpribadi (Devito, 2011). Pertama, komunikator harus terbuka kepada orang yang diajaknya berinteraksi (Devito, 2011). Hal ini terlihat pada upaya kedua narasumber untuk bersedia lebih aktif dan berinisiatif dalam menjalin interaksi dengan remaja tuna rungu. Kedua, kesediaan komunikator untuk bereaksi secara jujur terhadap stimulus yang datang (Devito, 2011). Para narasumber berpegang pada prinsip "Tidak ada yang lebih buruk daripada ketidakacuhan, bahkan ketidaksepakatan jauh lebih baik". Hal ini juga terlihat dari upaya kedua narasumber untuk menjadi pendengar setia yang terbuka untuk menampung semua hal yang diceritakan remaja tuna rungu (Bochner \& Kelly, 1974).

Selanjutnya hasil kategorisasi pendekatan humanistis untuk indikator mewakilkan pikiran dan perasaan memperlihatkan bahwa Narasumber 1, yaitu Jailim, S.Pd. cenderung mengutamakan pemenuhan kebutuhan bersosialisasinya sebagai upaya dalam mewakilkan perasaan dan pikiran remaja tuna rungu. Sedangkan sistem pendekatan yang dilakukan Narasumber 2, yaitu Mika Nur Cahyani, S.Pd. cenderung memberikan perhatian dan menunjukkan kehangatan agar anak mau bercerita. Secara keseluruhan upaya interaksi yang dilakukan kedua narasumber adalah menempatkan dirinya sebagai orang terdekat remaja tuna rungu, agar mereka dapat merasa nyaman untuk menceritakan segala hal kepada gurunya. Secara singkat, temuan penelitian cenderung mengonfirmasi teori Pendekatan Humanistis, bahwa orang yang memiliki empati cenderung mampu memahami motivasi, pengalaman, perasaan, sikap, serta harapan dan keinginan orang lain. Dengan adanya perasaan empati seseorang cenderung mampu menyesuaikan komunikasinya (Henry Backrack dalam Devito (2011).

Kemudian, hasil kategorisasi pendekatan humanistis dalam aspek sikap mendukung memperlihatkan hal berikut. Pertama, dari sisi Narasumber 1, menanamkan perilaku dan sikap untuk menghargai remaja tuna rungu layaknya sahabat: "Siswa, meski berkebutuhan khusus, juga perlu didukung. Dari hal sepele seperti memuji penampilannya, selalu bersikap ramah, menghormati pendapatnya, dan menganggap remaja tuna rungu sebagai siswa yang spesial. Bagi kita (manusia) yang normal, perlakuan seperti itu mungkin kecil (sepele), namun bagi anak-anak (remaja tuna rungu) ini, diperlakukan seperti itu sungguh berarti" (Jailim, Narasumber 1).

Kedua, dari sisi Narasumber 2, perilaku narasumber cenderung terbuka dan menerima remaja tuna rungu dengan baik, misalnya sering melibatkan anak-anak tuna rungu ke kegiatan masyarakat seperti mengisi acara kedinasan, mengikutkan lomba-lomba, mendirikan stand-stand pameran sehingga mereka lebih sering berkomunikasi dengan masyarakat umum. Secara keseluruhan bentuk pendekatan yang dilakukan kedua narasumber agar interaksi remaja tuna rungu ke masyarakat dapat terbuka dan meningkatkan rasa saling percaya antara murid dan guru. Temuan ini sejalan dengan apa yang dikatakan oleh Devito (2011) bahwa hubungan antarpribadi yang efektif dapat terbangun melalui sikap saling mendukung (supportiveness) di antara pihakpihak yang berkomunikasi. 
Selanjutnya, hasil kategorisasi pendekatan humanistis pada aspek sikap positif dan kesetaraan memperlihatkan temuan penelitian relatif sejalan dengan teori yang dirujuk. Seperti dilakukan oleh Narasumber 1 yang cenderung melakukan komunikasi yang hangat dan terbuka (sikap positif) agar menjadikan remaja tuna rungu setara atau sama kedudukannya sehingga tercipta suasana komunikasi yang terasa akrab dan nyaman tanpa menimbulkan jarak pemisah. Begitu pula yang dilakukan Narasumber 2 seperti memberikan rasa perhatian (sikap positif) dengan menunjukkan interaksi yang hangat dan bersahabat. Mereka meyakini dengan semangat berinteraksi yang hangat dapat menularkan arti penting berprestasi.

Lebih lanjut, jika dikaitkan dengan hasil kategorisasi pada perspektif interaksi simbolik, dapat terlihat dengan jelas bahwa upaya guru pembimbing dalam meningkatkan motivasi berprestasi remaja tuna rungu telah mengonfirmasi teori yang dikemukakan oleh West \& Turner (2010). Ada lima hal yang muncul dari hasil pengamatan terhadap dua narasumber dalam penelitian ini dalam kaitannya dengan interaksi simbolik untuk meningkatkan motivasi berprestasi remaja tuna rungu. Kelima hal tersebut antara lain melibatkan proses berpikir untuk menyelesaikan masalah, menanamkan rasa penghargaan diri, menanamkan stabilitas diri/emosional yang baik, meyakini kemampuan yang ada dalam diri, dan mengajak masyarakat untuk menyediakan ruang yang cukup untuk berinteraksi.

Terkait dengan konsep diri yang mengacu pada aspek psikologi remaja tuna rungu, penulis mencoba mendeskripsikan komposisi model dari kondisi psikologi remaja tuna rungu di SLB Negeri 4 Jakarta. Sebagaimana yang dijelaskan Demidenko et al., (2010), model yang terkait dengan kondisi psikologis yaitu penghargaan diri (self esteem), stabilitas diri (stability), dan tingkat keyakinan terhadap kemampuan diri (self efficacy). Pada aspek penghargaan diri, Narasumber 1 mempunyai sikap untuk membangun kepercayaan diri: "Jika remaja tuna rungu merasa dirinya diterima, maka akan muncul suatu perasaan yang nyaman dan aman untuk melakukan segala hal yang mereka inginkan.
Mereka akan merasa bahwa hidup mereka sangat berharga" (Jailim, Narasumber 1).

Karenanya, untuk menghadirkan rasa penghargaan diri yang tinggi, Narasumber 1 selalu bekerjasama dengan orang tua mereka untuk memantau dan mendampingi kehidupan siswa tuna rungu, baik di dalam maupun di luar sekolah. Apabila mereka memperoleh dukungan sosial yang berupa perhatian, kasih sayang, penghargaan, pertolongan, apresiasi dan sebagainya, maka mereka akan merasa ada yang mendukung. Selanjutnya, Narasumber 2 menanamkan self esteem dengan mengubah perannya sebagai motivator mereka: "Sebagai motivator, Saya bertugas untuk memotivasi anak-anak agar selalu memiliki rasa percaya diri yang tinggi. Memfasilitasi mereka untuk lebih maju, diantaranya dengan melibatkan kegiatan-kegiatan yang dilakukan oleh sekolah lain atau dalam kegiatan perlombaan yang menuntut mereka harus berani tampil di depan umum, karena semua itu dipercaya dapat meningkatkan rasa penghargaan diri dan percaya diri mereka" (Mika Nur Cahyani, Narasumber 2).

Pada aspek stabilitas diri, Narasumber 1 menanamkan pemahaman kepada remaja tuna rungu untuk menerima kondisi dirinya yang mempunyai gangguan pendengaran dan tidak perlu menyalahkan diri sendiri ataupun orang lain. Selalu memberikan rasa optimis agar mereka percaya diri dan tidak minder atas kekurangannya. Selanjutnya, Narasumber 2 dengan memberikan instruksi untuk "bersabar" melalui isyarat mengelus dada dan ekspresi wajah yang menunjukkan kesabaran: "Saya memberi pengertian pada anak-anak (remaja tuna rungu), bahwa jika kita bersabar maka akan disenangi teman-teman dan orang lain. Mendorong untuk tersenyum dan menyapa setiap orang yang dikenalnya. Memberikan contoh "marah" melalui ekspresi wajah dan memberi pemahaman bahwa jika mudah marah maka akan dijauhi oleh teman-teman" (Mika Nur Cahyani, Narasumber 2).

Apa yang dijelaskan oleh Narasumber 2 terkait stability, cenderung mengonfirmasi teori pendekatan perilaku nonverbal yang mendefinisikan gerak isyarat atau gesture merupakan gerakan tangan, lengan dan jari-jari yang kita gunakan untuk menjelaskan atau 
untuk menegaskan (Paul Ekman dan Wallace V. Friesen dalam Devito (2011).

Pada aspek tingkat keyakinan terhadap kemampuan diri, Narasumber 1 menggunakan pendekatan nonverbal sambil bergurau. Memberikan motivasi dengan bahasa-bahasa yang ringan namun tetap mendorong dengan serius agar tumbuh rasa keyakinan terhadap kemampuan diri yang dimiliki. Sedangkan Narasumber 2, mengupayakan untuk memberikan apresiasi atas pencapaian yang dilakukan seperti membuatkan sertifikat atau reward lainnya.

Kemudian, aspek society yang terdapat pada teori interaksi simbolik, Mead menjelaskan bahwa pranata sosial seharusnya hanya menetapkan apa yang sebaiknya dilakukan individu dalam pengertian yang umum saja, sehingga tersedia ruang yang cukup bagi individualitas dan kreativitas. Dalam hal ini, Mead menunjukkan konsep pranata sosial yang sangat modern, yang memungkinkan mereka untuk menjadi individu kreatif (Ritzer dan Goodman, 2007).

Hal tersebut telah tergambar pada pernyataan kedua narasumber. Pertama, dalam mengajak peran serta masyarakat dan warga sekolah dengan mendukung sarana sekolah seperti adanya lapangan yang besar, karena dengan lapangan inilah mereka dapat berinteraksi dan bermain dengan bebas tanpa ada sekat-sekat layaknya di ruang kelas. Dengan adanya kegiatan bersama di lapangan seperti aktivitas berdoa bersama, senam bersama, kegiatan olahraga, pentas seni, praktek belajar kewirausahaan diharapkan menjadi ruang interaksi antara remaja tuna rungu dengan warga sekolah tanpa terkecuali, sehingga diharapkan muncul pribadi yang kreatif dan berprestasi.

Kedua, yang memberikan kesempatan kepada semua remaja tuna rungu untuk mencoba semua kegiatan ekstrakurikuler yang disenanginya, memberikan pengertian kepada orang tua agar di rumah melatih mereka sesuai dengan minat yang disenangi saat kegiatan ekstrakurikuler sekolah. Jika sudah muncul bakat, maka guru akan mengikutsertakan mereka ke lomba-lomba yang disediakan oleh dinas. Memberikan kesempatan kepada remaja tuna rungu untuk mengikuti lomba apa saja yang diinginkan. Jika ada yang malu, maka latihan melakukan lomba di tingkat sekolah terlebih dahulu. Dengan demikian mereka akan terbiasa mau menunjukkan kemampuannya, dan dapat mengikuti kompetisi di luar sekolah. Serta memberikan kesempatan kepada remaja tuna rungu untuk mengisi kegiatan di acara kedinasan maupun acara-acara masyarakat umum sebagai pengisi acara seperti menari, pantomim, berakting, fashion show. Melalui acara-acara seperti ini pula masyarakat umum diharapkan dapat terbiasa dan menerima kehadiran remaja tuna rungu. Adapun rangkuman dari temuan penelitian dapat dilihat pada Tabel 2 .

Tabel 2

Rangkuman Temuan Penelitian

\begin{tabular}{lll}
\hline $\begin{array}{l}\text { Aspek } \\
\text { Penelitian }\end{array}$ & Dimensi & \multicolumn{1}{c}{ Bentuk Tindakan } \\
\hline $\begin{array}{l}\text { Pendekatan } \\
\text { humanistis }\end{array}$ & Keterbukaan & $\begin{array}{l}\text { Lebih aktif dan berinisiatif dalam menjalin interaksi dengan remaja tuna } \\
\text { rungu. }\end{array}$ \\
& $\begin{array}{l}\text { Berpegang pada prinsip "tidak ada yang lebih buruk daripada } \\
\text { ketidakacuhan". } \\
\text { Menjadi pendengar setia yang terbuka untuk menampung semua hal } \\
\text { yang diceritakan remaja tuna rungu. } \\
\end{array}$ & $\begin{array}{l}\text { Mengutamakan pemenuhan kebutuhan bersosialisasi sebagai upaya } \\
\text { dalam mewakilkan perasaan dan pikiran remaja tuna rungu. }\end{array}$ \\
& Empati & $\begin{array}{l}\text { Memuji penampilan, selalu bersikap ramah, menghormati pendapat, } \\
\text { dan menganggap remaja tuna rungu sebagai siswa yang spesial. }\end{array}$ \\
& Sikap mendukung & Melibatkan anak tuna rungu pada kegiatan masyarakat, seperti mengisi \\
& acara kedinasan, mengikutkan pada lomba-lomba, mendirikan stand- \\
& stand pameran sehingga mereka lebih sering berkomunikasi dengan \\
& masyarakat umum. \\
& Melakukan komunikasi yang hangat dan terbuka.
\end{tabular}




\begin{tabular}{|c|c|c|}
\hline & & $\begin{array}{l}\text { Memberikan rasa perhatian (sikap positif) dengan menunjukkan } \\
\text { interaksi yang hangat dan bersahabat. }\end{array}$ \\
\hline & Kesetaraan & $\begin{array}{l}\text { Menjadikan remaja tuna rungu setara atau sama kedudukannya } \\
\text { sehingga tercipta suasana yang akrab dan nyaman tanpa menimbulkan } \\
\text { jarak pemisah. }\end{array}$ \\
\hline \multirow[t]{3}{*}{$\begin{array}{l}\text { Interaksi } \\
\text { simbolik }\end{array}$} & $\begin{array}{l}\text { Kemampuan berpikir } \\
\text { (mind) }\end{array}$ & $\begin{array}{l}\text { Memberi pengertian pada anak-anak (remaja tuna rungu), bahwa jika } \\
\text { kita bersabar maka akan disenangi teman-teman dan orang lain. } \\
\text { Sebaliknya, jika mudah marah maka akan dijauhi oleh teman-teman. } \\
\text { Mengupayakan untuk memberikan apresiasi atas pencapaian yang } \\
\text { dilakukan seperti membuatkan sertifikat atau reward lainnya. }\end{array}$ \\
\hline & $\begin{array}{l}\text { Menerapkan konsep } \\
\text { diri yang positif (self) }\end{array}$ & $\begin{array}{l}\text { Menanamkan pada remaja tuna rungu untuk menerima kondisi dirinya } \\
\text { dan tidak menyalahkan diri sendiri ataupun orang lain. } \\
\text { Memberikan rasa optimis agar mereka percaya diri dan tidak minder } \\
\text { atas kekurangannya. } \\
\text { Memotivasi agar selalu memiliki rasa percaya diri yang tinggi dengan } \\
\text { melibatkan mereka dalam perlombaan atau eksebisi (pertunjukan) } \\
\text { sebagai ajang melatih mental siswa tuna rungu untuk berani tampil di } \\
\text { depan umum. }\end{array}$ \\
\hline & $\begin{array}{l}\text { Penerimaan } \\
\text { masyarakat (society) }\end{array}$ & $\begin{array}{l}\text { Bekerjasama dengan orang tua untuk memantau dan mendampingi } \\
\text { kehidupan siswa tuna rungu, baik di dalam maupun di luar sekolah. } \\
\text { Mengajak peran serta masyarakat dan warga sekolah dengan } \\
\text { mendukung sarana sekolah, seperti adanya lapangan yang besar sebagai } \\
\text { ruang interaksi antara remaja tuna rungu dengan warga sekolah. }\end{array}$ \\
\hline $\begin{array}{l}\text { Komunikasi } \\
\text { nonverbal }\end{array}$ & $\begin{array}{l}\text { Kinesik (gerakan } \\
\text { tubuh) } \\
\text { Paralanguage (suara) }\end{array}$ & $\begin{array}{l}\text { Memberikan instruksi untuk "bersabar" melalui isyarat mengelus dada } \\
\text { dan ekspresi wajah yang menunjukkan kesabaran. } \\
\text { Saat berbicara dengan siswa tuna rungu, harus tepat kapan } \\
\text { menggunakan nada dan intonasi tinggi dan rendah, disesuaikan dengan } \\
\text { konteks dan suasana hati mereka. }\end{array}$ \\
\hline
\end{tabular}

Sumber: Semua subjek penelitian.

\section{PENUTUP}

\section{Simpulan}

Pengalaman komunikasi interpersonal guru dalam meningkatkan motivasi berprestasi remaja tuna rungu berfokus pada pendekatan humanistis seperti adanya keterampilan membangun dan menjaga relasi yang hangat, mengajarkan kepercayaan diri, keterbukaan, memahami perasaan, kejujuran interpersonal, dan kesetaraan. Pengalaman komunikasi interpersonal guru dalam meningkatkan motivasi berprestasi remaja tuna rungu juga menitikberatkan pada perspektif interaksi simbolik seperti menanamkan kemampuan berpikir dalam menyelesaikan permasalahan, menerapkan konsep diri yang berkualitas, dan melibatkan masyarakat untuk memenuhi kebutuhan berinteraksi.

Pengalaman komunikasi interpersonal guru dalam meningkatkan motivasi berprestasi remaja tuna rungu juga mengedepankan pentingnya perilaku nonverbal. Hal ini terlihat pada upaya guru dengan menggunakan isyarat nonverbal seperti gerakan dan ekspresi ketika bermaksud mengkomunikasikan suatu hal. Selain itu guru juga memahami waktu yang tepat untuk menggunakan nada tinggi atau rendah saat berkomunikasi dengan remaja tuna yang disesuaikan dengan suasana hati remaja tuna rungu saat itu. Hal ini dilakukan atas dasar pemahaman guru terkait tingkat sensitivitas remaja tuna rungu yang dinamis.

\section{Saran}

Bagi penelitian selanjutnya untuk dapat berfokus pada salah satu pendekatan yang digunakan dalam penelitian ini, antara lain pendekatan humanistis, interaksi simbolis, atau penggunaan komunikasi nonverbal. Dapat juga dilakukan dengan menggunakan metode kuantitatif untuk melihat tingkat pengaruh pendekatan humanistis, interaksi simbolis, dan penggunaan komunikasi nonverbal dalam membentuk prestasi remaja tuna rungu. 


\section{DAFTAR PUSTAKA}

Ardianto, E., Komala, L. \& Karlinah, S. (2007) Komunikasi Massa: Suatu Pengantar. Bandung, Simbiosa Rekatama.

Aw, S. (2011) Komunikasi Interpersonal. 1st edition. Yogyakarta, Graha Ilmu.

Bochner, A.P. \& Kelly, C.W. (1974) Interpersonal competence: Rationale, philosophy, and implementation of a conceptual framework. The Speech Teacher. [Online] 23 (4), 279301. Available from: doi:10.1080/03634527409378103.

Brown, P.M., Remine, M.D., Prescott, S.J. \& Rickards, F.W. (2000) Social Interactions of Preschoolers With and Without Impaired Hearing in Integrated Kindergarten. Journal of Early Intervention. [Online] 23 (3), 200-211. Available from: doi:10.1177/10538151000230030901.

Budyatna, M. \& Ganiem, M. (2011) Teori Komunikasi Antarpribadi. Jakarta, Kencana.

Dasrun, H. (2012) Komunikasi Antarpribadi dan Medianya. Yogyakarta, Graha Ilmu.

Demidenko, N., Tasca, G.A., Kennedy, N. \& Bissada, H. (2010) The Mediating Role of Self-Concept in the Relationship Between Attachment Insecurity and Identity Differentiation Among Women with an Eating Disorder. Journal of Social and Clinical Psychology. [Online] 29 (10), 1131-1152. Available from: doi:10.1521/jscp.2010.29.10.1131.

Devito, J.A. (2011) Komunikasi Antarmanusia. 5th edition. Tangerang, Karisma Publishing Group.

Heryati, E. (2012) Profil Kebutuhan Psikologi Remaja Tunarungu. Jurnal Pedagogia. 10, 9 23.

Kementerian Pendidikan dan Kebudayaandikbud (2020) Data Kemdikbud 2020.

Komariah, A. \& Satori, D. (2014) Metode Penelitian Kualitatif. Bandung, Alfabeta.

Kountur, Ronny (2008) Metode Penelitian untuk Penulisan Skripsi dan Tesis. Jakarta, PPM Manajemen.

Lestari, S. (2012) Psikologi Keluarga: Penanaman Nilai Dan Penanganan Konflik Dalam Keluarga. Jakarta, Kencana.

Liben, L.S. (1978) Developmental Perspectives on the Experiential Deficiencies of Deaf Children. In: Deaf Children. [Online]. Elsevier. pp. 195-215. Available from: doi:10.1016/B978-0-12-447950-0.50016-2.
Littlejohn, S.W. \& Foss, K.A. (2009) Theories Of Human Communication. Wadsworth Publishing Company (ed.). California, Cambridge University Press.

Mulyana, D. (2015) Ilmu Komunikasi: Suatu Pengantar. Bandung, Remaja Rosdakarya.

Pranungsari, D., Tentama, F. \& Tarnoto, N. (2016) Achievement Motivation Training (AMT) Sebagai Upaya Mencegah Kenakalan Remaja. In: Jabrohim \& Rina Ratih Sri Sudaryani (eds.). Seminar Nasional: Pemanfaatan Ipteks dalam Membangun Desa Mandiri dan Religius. 2016 Yogyakarta, Pustaka Pelajar. pp. 58-72.

Ritzer, G. \& Goodman, D.J. (2007) Teori Sosiologi Modern. Jakarta, Kencana Prenada Media Group.

Senorita, Z., Silalahi, B. \& Manullang, J. (2018) Terbatas Kemampuan Terhadang Akses Pendidikan. [Online]. 2018. Available from: https://www.validnews.id/TerbatasKemampuan-Terhadang-Akses-PendidikanRQh [Accessed: 20 January 2018].

Soekanto, S. (1990) Sosiologi Suatu Pengantar, Edisi IV. In: Jakarta, Penerbit Rajawali. p.

Somantri, S. (2007) Psikologi Anak Luar Biasa. Bandung, Refika Aditama.

Sugiyono (2017) Metode Penelitian Bisnis (Pendekatan Kuantitatif, Kualitatif, Kombinasi dan R\&D).

Sukadji (2001) Motivasi dalam Masyarakat. Jakarta, Gramedia.

Suparno (2001) Pendidikan Anak Tuna Rungu. Yogyakarta, FIP Universitas Negeri Yogyakarta.

Wandi (2016) Banyak Anak Berkebutuhan Khusus Tidak Bisa Sekolah. [Online]. 2016. Available from:

http://poskotanews.com/2016/12/09/banyakanak-berkebutuhan-khusus-tidak-bisasekolah/ [Accessed: 15 October 2018].

West, R. \& Turner, L.H. (2010) Introduction Communication Theory Analysis and Application. 4th edition. The McGraw-Hill Companies.

Widinarsih, D. (2019) Penyandang Disabilitas di Indonesia: Perkembangan Istilah dan Definisi. Jurnal Ilmu Kesejahteraan Sosial. [Online] 20 (2). Available from: http://jurnalkesos.ui.ac.id/index.php/jiks/artic le/view/239.

Yusuf, M. (2017) Metode Penlitian Kuantitatif, Kualitatif \& Penelitian Gabungan. Jakarta, Kencana. 